\title{
Safety profile of Td vaccination in Indonesian pregnant women: a post-marketing surveillance study
}

Hindra Irawan Satari, ${ }^{1,2}$ Mita Puspita, ${ }^{3}$ Julitasari Sundoro, ${ }^{2}$ Andrijono, ${ }^{2}$ Syafriyal, ${ }^{2}$ Rini Mulia Sari, ${ }^{3}$ Novilia Sjafri Bachtiar, ${ }^{3}$ Sri Rezeki Hadinegoro ${ }^{2}$

pISSN: 0853-1773 • elSSN: 2252-8083 https://doi.org/10.13181/mji.v28i4.3321 Med J Indones. 2019;28:322-8

Received: December 18, 2018

Accepted: May 15, 2019

\section{Authors' affiliations:}

${ }^{1}$ Department of Child Health, Faculty of Medicine, Universitas Indonesia, Cipto Mangunkusumo Hospital, Jakarta, Indonesia, 'Indonesian Vaccine Safety Advisory Committee, Jakarta, Indonesia, ${ }^{3}$ PT Bio Farma, Bandung, Indonesia

\section{Corresponding author:}

Mita Puspita

PT Bio Farma, Jalan Pasteur No. 28,

Bandung 40161, Indonesia

Tel/Fax: +62-22-2033755 ext. 14100

E-mail: mita.puspita@biofarma.co.id

\begin{abstract}
BACKGROUND The Indonesian Expanded Program of Immunization has implemented tetanus and diphtheria $(\mathrm{Td})$ vaccination to replace the tetanus toxoid vaccine in pregnant women since the year 2016. Td vaccine is administered to protect against diphtheria and tetanus to the mother and her baby as well. This prospective study was conducted to assess the adverse reactions after Td immunization; besides, a retrospective study was conducted to observe the presence of severe local reaction (Arthus reaction), premature birth, and low birth weight history in the medical records of pregnant women who had received Td immunization in the past year.
\end{abstract}

METHODS A prospective observational study was conducted in 200 pregnant women. Local reactions and systemic events occurring within 28 days after immunization were recorded in the diary card and were confirmed by the health worker in the follow-up visit. A retrospective study was also conducted to evaluate 750 medical records of pregnant women who had received Td immunization. The study was conducted from September 2017 to January 2018. The study has been registered at ClinicalTrials.gov ID: NCT03383653.

RESULTS In 185 pregnant women who completed the study, the most common local reaction was pain, occurring in $33.5 \%$ of subjects within 24 hours after vaccination. Fever, other systemic reactions, and serious adverse events were not reported during the observation. In the retrospective study, 647 medical records were validated. No Arthus reaction was observed. The prevalence of premature birth was $1.24 \%$, and that of low birth weight was $2.63 \%$, which were below the normal rates.

CONCLUSIONS Td vaccination in pregnant women was safe and well-tolerated.

KEYWORDS adverse drug event, low birth weight, pregnant women, premature birth, tetanus vaccine
Vaccination can reduce the rates of disease and death in children and women in reproductive age. Different immune reactions occurring in pregnant women can alter the immune system in responding to the disease antigen and may harm both the mother and the baby. Immunization can have beneficial effects in protecting both the mother and the fetus from infection by several pathogens. ${ }^{1}$ It has been reported that there are approximately 15 million women of childbearing age in Indonesia, of whom 5 million are supposed to become pregnant every year. ${ }^{2}$
Safe immunization for pregnant women includes diphtheria, pertussis, tetanus, influenza, and hepatitis $B$ with meningococcal and rabies vaccine as another option. No live vaccines such as measles, mumps, rubella, varicella, and Bacillus Calmette-Guérin can be administered as they could harm the fetus. The riskbenefit ratio must be considered when administering vaccines to a pregnant woman. ${ }^{3}$

Tetanus disease in a newborn baby can be avoided by tetanus toxoid (TT) and tetanus and diphtheria (Td) immunization, which has been implemented in 
most countries across the world. Furthermore, the safety of TT vaccination in pregnant women has been established. ${ }^{4}$ Although diphtheria has been reported to be distributed worldwide, it is currently rare in Western Europe and the US since the introduction of effective vaccination programs. Diphtheria is still endemic in several parts of the world, particularly in Southeast Asian countries, with a high case fatality rate of $3.5-12 \%$. Although active immunization programs have reduced the incidence of the disease, they should also be followed by high immunization coverage to decrease the mortality and morbidity rates. ${ }^{5}$

During the years 2000-2002, the hospital incidence rate of diphtheria cases in Indonesia was found to be the highest among outpatients and inpatients in the age range of $15-44$ years $(37.42 \%)$ and $1-4$ years $(39.02 \%)$, respectively. ${ }^{6}$ Data based on primary health centers revealed high incidence rate of diphtheria in the age group of $15-44$ years. ${ }^{6}$ Meanwhile, the incidence of diphtheria outbreak in East Java had increased during 2003-2009. Concerning the increasing incidence of diphtheria in some provinces, the Indonesian Technical Advisory Group of Immunization (ITAGI) recommended in 2010 that TT vaccination be replaced with Td vaccination for women of childbearing age. ${ }^{7}$ Supporting this recommendation, the Ministry of Health replaced TT with $\mathrm{Td}$ vaccination for women of childbearing age and pregnant women. ${ }^{8}$ This was the first time that $\mathrm{Td}$ vaccination was used in pregnant women in Indonesia; therefore, this investigation was conducted as postmarketing surveillance (PMS) study.

The objectives of the prospective study were to assess the local reactions, the systemic events, and any serious adverse events that occur after immunization with the Td vaccine in pregnant women. These adverse reactions should be monitored intensively for the first 3 days and continued for the subsequent 25 days. In the retrospective study, the aim was to obtain information regarding the Arthus reaction (Type III hypersensitivity reaction), premature birth, and low birth weight after Td immunization.

\section{METHODS}

This observational study was conducted with prospective and retrospective data collection methods. In the prospective study, 200 pregnant women aged 18-39 years were enrolled, while 750 medical record of pregnant women who had received Td vaccination were included in the retrospective study consecutively. The study was conducted from September 2017 to January 2018. Both the prospective and retrospective studies were conducted in 15 primary health centers in Jakarta, Indonesia.

Pregnant women aged 18-39 years with 27-36 weeks of gestation and having been informed about the nature of the study, willing to be involved, and will not receive any vaccination within 1 month before and after Td immunization were eligible to participate in the prospective study. The retrospective study evaluated the medical records of pregnant women aged 18-39 years who had received Td vaccination between May 2016 and May 2017 and no history of spontaneous abortion, stillbirth, ectopic pregnancy or twin pregnancy, with documented delivery outcomes. Signed informed consent was obtained from all subjects before conducting the prospective study.

The sample size for the prospective study was calculated using proportion formula with $95 \%$ confidence interval and power $80 \%$, considering the incidence rate of local reactions following tetanus immunization of $7.4 \%$. Accordingly, the study required 159 subjects; therefore, considering approximately $20 \%$ dropout, it would need around 200 subjects. The same formula was also used for the retrospective study, with the highest sample size of 704 data consisting of approximately $20 \%$ invalid data, requiring 750 medical records. This calculation was based on the incidence rate of $2 \%$ for the Arthus reaction.

\section{Procedures}

The study protocol was reviewed and approved by the Ethics Committee of the Faculty of Medicine, Universitas Indonesia (No: 452/UN.F1/ETIK/2017). The study has been registered at ClinicalTrials.gov ID: NCT03383653.

After obtaining the signed informed consent, the subjects who met the inclusion criteria were allocated to an inclusion number from 001 to 200 for the prospective study. The subjects had received $\mathrm{Td}$ vaccination according to the immunization schedule of the National Immunization Program. All subjects were provided with a diary card to assess and record information regarding local and systemic reactions that occurred within 28 days after immunization, with special attention during the first 3 days. Local reactions were those that developed at the injection site, and 
systemic reactions were those that were experienced systemically outside the injection site. Both the local and systemic adverse events were monitored and recorded, including immediate, delayed, and serious adverse events (SAEs). Safety assessments were conducted and confirmed by a trained health care provider within $30 \mathrm{~min}$ after the administration of injection. Subjects received thermometers, plastic bangles, and diary cards to record the occurrence of local and systemic reactions. The intensity (recorded as $1=$ mild, $2=$ moderate, or $3=$ severe) of local reactions (pain, redness, swelling, and induration at the injection site) and systemic reactions (fever $\geq 38^{\circ} \mathrm{C}$ and irritability) was recorded from day o through day 28 after immunization. For local reactions (redness, swelling, or induration), grades 1, 2, and 3 were defined as areas $<5,5-10$, and $>10 \mathrm{~cm}$ in diameter, respectively, using the plastic bangle. Pain of grade 1 was defined as mild discomfort to touch, grade 2 pain was defined as discomfort with movement, and grade 3 pain was defined as significant discomfort at rest. Regarding systemic reactions, fever of grade 1 was defined as an axillary temperature of $\geq 38.0-38.5^{\circ} \mathrm{C}$, grade 2 fever was defined at $>38.5-39.0^{\circ} \mathrm{C}$, and grade 3 fever was defined when the temperature was $>39^{\circ} \mathrm{C}$. Any other systemic reactions such as diarrhea, vomiting, and myalgia were also evaluated. For all other adverse events, grade 3 was defined as unable to do normal daily activities.9-12

The data for the retrospective study were collected from the medical records of pregnant women who had received $\mathrm{Td}$ vaccination within the past year. Details about the adverse events were collected from the medical records, including the Arthus reaction in mothers after the vaccination, mothers with low birth weight infants, and/or mothers with premature births. The Arthus reaction is a severe local reaction that is considered to be caused due to hypersensitivity reaction to immune complexes. It can be manifested as a painful swelling that extends from the shoulder to the elbow and occurs 2-8 hours after the vaccination. It can be experienced by hyperimmunized persons, most often in adults, and occasionally reported after frequent vaccination containing diphtheria-tetanus toxoid. Extremely high serum antitoxin levels are generally found in these people with the Arthus reaction. It has been recommended that these people should not receive a routine or emergency booster of Td vaccination in less than 10 years. ${ }^{33,14}$ A premature birth occurs before the start of the $37^{\text {th }}$ week of pregnancy. ${ }^{15}$
Low birth weight is defined as a birth weight of $<2,500$ g. ${ }^{16}$ In the prospective study, the percentage of events that occurred will be presented in $30 \mathrm{~min}, 24,48$, and 72 hours until 28 days after immunization, while the percentage of Arthus reactions, premature birth, and low birth weight were calculated in the retrospective study.

\section{RESULTS}

\section{Prospective study}

Of the total 200 pregnant women enrolled in this study, 185 completed the study, aged between 18-38 years old (Table 1) and their data could be analyzed, whereas 15 subjects were dropped out due to an error that occurred when filling in the diary card due to which the data could not be confirmed. The history of tetanus based vaccine is presented in Table 2, where $9.7 \%$ of subjects received vaccines more than three times. Pain was the most commonly reported reaction to $\mathrm{Td}$ immunization that occurred within 24 hours (33.5\%),

Table 1. Demographic data

\begin{tabular}{|lc|}
\hline Variables & $\mathrm{n}(\%)(\mathrm{N}=185)$ \\
\hline Age of mother (years) & $126(68.1)$ \\
\hline $18-30$ & $59(31.9)$ \\
\hline $31-38$ & \\
\hline Gestational age (weeks) & $80(43.2)$ \\
\hline $27-30$ & $47(25.4)$ \\
\hline $31-33$ & $58(31.4)$ \\
\hline $34-36$ & $22(11.9)$ \\
\hline Education & $29(15.7)$ \\
\hline Primary School & $107(57.8)$ \\
\hline Secondary School & $10(5.4)$ \\
\hline Senior High School & $17(9.2)$ \\
\hline Diploma & \\
\hline Bachelor Degree & \\
\hline
\end{tabular}

Table 2. History of tetanus toxoid (TT) vaccination in the prospective study

\begin{tabular}{lc}
\hline Frequency of TT vaccination & $\mathrm{n}(\%)(\mathrm{N}=185)$ \\
\hline 0 & $51(27.6)$ \\
1 & $46(24.9)$ \\
2 & $50(27)$ \\
3 & $20(10.8)$ \\
4 & $16(8.6)$ \\
5 & $2(1.1)$ \\
\hline
\end{tabular}


Table 3. Systemic and local reactions after tetanus and diphtheria (Td) immunization in the prospective study
Table 4. Local reactions after tetanus and diphtheria (Td) immunization in subjects who have received more than three times of the tetanus vaccine in the prospective study

\begin{tabular}{lccccc}
\hline \multirow{2}{*}{ Intensity } & \multicolumn{5}{c}{ Observation time, $\mathrm{n}(\%)$} \\
\cline { 2 - 6 } & $30 \mathrm{~min}$ & Day 1 & Day 2 & Day 3 & Day 4-28 \\
\hline Systemic reactions & & & & \\
\hline Fever & $0(0)$ & $0(0)$ & $0(0)$ & $0(0)$ & $0(0)$ \\
\hline Other & $0(0)$ & $0(0)$ & $0(0)$ & $0(0)$ & $0(0)$ \\
Local reactions & & & & \\
\hline Pain & $14(7.6)$ & $15(8.1)$ & $12(6.5)$ & $8(4.3)$ & $2(1.1)$ \\
\hline Mild & $19(10.3)$ & $31(16.8)$ & $20(10.8)$ & $6(3.2)$ & $0(0)$ \\
\hline Moderate & $11(5.9)$ & $16(8.6)$ & $9(4.9)$ & $5(2.7)$ & $0(0)$ \\
\hline Severe & $44(23.8)$ & $62(33.5)$ & $41(22.2)$ & $19(10.3)$ & $2(1.1)$ \\
\hline Total & & & & & \\
\hline Redness & $7(3.8)$ & $10(5.4)$ & $9(4.9)$ & $3(1.6)$ & $4(2.2)$ \\
\hline Mild & $3(1.6)$ & $5(2.7)$ & $3(1.6)$ & $2(1.1)$ & $1(0.5)$ \\
\hline Moderate & $0(0)$ & $1(0.5)$ & $0(0)$ & $1(0.5)$ & $0(0)$ \\
\hline Severe & $10(5.4)$ & $16(8.6)$ & $12(6.5)$ & $6(3.2)$ & $5(2.7)$ \\
\hline Total & & & & & \\
\hline Swelling & $4(2.2)$ & $8(4.3)$ & $8(4.3)$ & $5(2.7)$ & $3(1.6)$ \\
\hline Mild & $0(0)$ & $0(0)$ & $1(0.5)$ & $0(0)$ & $0(0)$ \\
\hline Moderate & $0(0)$ & $0(0)$ & $0(0)$ & $0(0)$ & $0(0)$ \\
\hline Severe & $4(2.2)$ & $8(4.3)$ & $9(4.7)$ & $5(2.7)$ & $3(1.6)$ \\
\hline Total & & & & \\
\hline & & & & \\
\hline
\end{tabular}

\begin{tabular}{|c|c|c|c|c|c|}
\hline \multirow{2}{*}{ Intensity } & \multicolumn{5}{|c|}{ Observation time, n (\%) } \\
\hline & $30 \mathrm{~min}$ & Day 1 & Day 2 & Day 3 & Day 4-28 \\
\hline \multicolumn{6}{|l|}{ Local pain } \\
\hline Mild & $1(5.5)$ & $3(16.7)$ & $2(11)$ & $1(5.5)$ & $0(0)$ \\
\hline Moderate & $0(0)$ & $1(5.5)$ & $0(0)$ & $0(0)$ & $0(0)$ \\
\hline Severe & $1(5.5)$ & $2(11)$ & $3(16.7)$ & $0(0)$ & $0(0)$ \\
\hline Total & $2(11)$ & $6(33.2)$ & $5(27.7)$ & $1(5.5)$ & $0(0)$ \\
\hline \multicolumn{6}{|l|}{ Redness } \\
\hline Mild & $2(11.1)$ & $3(16.7)$ & $2(11.1)$ & $1(5.5)$ & $1(5.5)$ \\
\hline Moderate & $0(0)$ & $0(0)$ & $0(0)$ & $0(0)$ & $0(0)$ \\
\hline Severe & $0(0)$ & $0(0)$ & $0(0)$ & $1(5.5)$ & $0(0)$ \\
\hline Total & $2(11.1)$ & $3(16.7)$ & $2(11.1)$ & $2(11.1)$ & $1(5.5)$ \\
\hline \multicolumn{6}{|l|}{ Swelling } \\
\hline Mild & $0(0)$ & $0(0)$ & $1(5.5)$ & $0(0)$ & $1(5.5)$ \\
\hline Moderate & $0(0)$ & $0(0)$ & $0(0)$ & $0(0)$ & $0(0)$ \\
\hline Severe & $0(0)$ & $0(0)$ & $0(0)$ & $0(0)$ & $0(0)$ \\
\hline Total & $0(0)$ & $0(0)$ & $1(5.5)$ & $0(0)$ & $1(5.5)$ \\
\hline
\end{tabular}

and the majority of subjects had pain with moderate intensity (16.8\%) (Table 3).

Attention to 18 subjects from 185 (9.72\%) who received tetanus-containing vaccine more than three times (Table 4), we reported one third showed local pain at 24 hours (33.2\%), and severe pain at 48 hours after immunization (16.7\%). Redness reported in 3 (16.7\%) after 24 hours and severe redness 5.5\% at 72 hours following vaccination. One subject experienced mild swelling at 48 hours following immunization. No systemic reaction, as well as fever, was reported in this study. 
Table 5. Details of subjects who experienced the Arthus reaction, premature birth, and low birth weight infants in the retrospective study

\begin{tabular}{lc}
\hline Variables & $\mathrm{n}(\%)(\mathrm{N}=647)$ \\
\hline Arthus reaction & $0(0)$ \\
Birth history & \\
\hline \multicolumn{1}{l}{ Aterm } & $639(98.76)$ \\
Preterm & $8(1.24)$ \\
Birth weight & \\
$\geq 2,500 \mathrm{~g}$ & $630(97.37)$ \\
$<2,500 \mathrm{~g}$ & $17(2.63)$ \\
\hline
\end{tabular}

\section{Retrospective study}

Analyzed in retrospective study taken from 647 medical records to show Arthus reaction, premature birth, and low birth weight in pregnant women who had received $\mathrm{Td}$ vaccine at the time of pregnancy. Data collected from 15 Primary Health Care in Jakarta Province. Subjects 18-39 years of age were enrolled, with the mean age at 30 years. Table 5 shows that there were no Arthus reactions, $1.24 \%$ preterm birth and $2.63 \%$ low birth weight. Among subjects who had received more than three times of the $\mathrm{Td}$ vaccine, $2.16 \%$ had swelling at the site of injection, of whom $71.42 \%$ required medication. However, all the subjects recovered completely, and none of them were confirmed as the Arthus reaction.

\section{DISCUSSION}

This investigation was a PMS study of Td vaccination in pregnant women. A group of experts from the Advisory Committee on Immunization Practices suggested that personnel involved in women's health care should vaccinate pregnant women who have previously not received the tetanus, diphtheria, pertussis (Tdap) vaccine. This vaccine is recommended during the third or late second trimester or as soon as possible during the postpartum period. TT and $\mathrm{Td}$ vaccines, which are inexpensive than Tdap vaccine, have been used in pregnant women in several countries to avert neonatal tetanus, and large-scale studies have also reported no clinically significant severe adverse events associated with them. ${ }^{17}$

Safety data from the World Health Organization (WHO) information sheet have documented the observed rate of adverse events after immunization with the combined vaccine containing the diphtheria, pertussis, and tetanus antigen described mostly caused by TT, whereas the data caused by diphtheria was not documented yet. ${ }^{12} \mathrm{~A}$ trial of $\mathrm{Td}$ vaccination (Bio Farma ${ }^{\circledR}$ production) evaluated 150 healthy adolescent individuals in Bandung province. Pain as a local reaction at the injection site was observed in $20.3 \%$ of the subjects. No SAEs were reported, and the most local and systemic reactions were mild and well-tolerated. The most common systemic reaction was fever that was observed in $0.7-4.7 \%$ of the study subjects, depending on the time of onset. ${ }^{18}$

A PMS study was conducted in elementary schools in East Java province in 2010. The sample size based on the calculated formula was 3,000 subjects from three locations (Pamekasan, Gresik, and Mojokerto regencies) and were distributed proportionally to 48 elementary schools/Islamic schools. Td vaccines were administered to $2^{\text {nd }}$ and $3^{\text {rd }}$ levels of elementary/Islamic school children replacing the TT vaccine according to the Routine School Immunization Program. A total of 159 subjects were evaluated to assess the efficacy of the vaccine against $\mathrm{Td}$ antibodies. There were no serious systemic reactions reported within 30 min after Td immunization; however, at 72 hours, there were mild local and systemic reactions reported among 0.37$83.38 \%$ of the subjects. The most common reaction was local pain at the injection site on the first day after immunization. ${ }^{19}$

In this study, there was no systemic reaction such as fever, myalgia, or dizziness after the first dose of immunization with the $\mathrm{Td}$ vaccine. Furthermore, no SAEs occurred during the study. Unfortunately, studies on other Td or Tdap vaccines in pregnant women from a developing country have not yet been published, due to which we could not make a comparison at this moment. When compared with the bridging study of this vaccine in adolescents, the incidence of systemic reaction found in this study was very low..$^{18}$ Compared with a similar study on Tdap vaccine in New Zealand, the incidence of fever was $2.1 \%$, and that of other systemic reactions (headache, dizziness, nausea, myalgia, and arthralgia) was $<4 \%{ }^{20}$ According to the $\mathrm{WHO}$, the incidence of other systemic reactions such as fever and malaise may be $1.7 \%$ and $5.1 \%$, respectively. ${ }^{13}$ Thus, the rate of systemic reactions observed in this study are lower than that reported in the abovementioned studies.

In this study, local reactions were analyzed separately as those that were experienced by people 
who had received the tetanus vaccine containing antibody titers below or equal to three times with more than three times. Receiving more than three times of $\mathrm{Td}$ vaccination was separated in the analysis with the assumption that the subject had already received more than six times of immunization, including the primary doses received during childhood. According to the WHO, receiving six times of immunization with the tetanus vaccine may protect the subject for the entire life. ${ }^{21}$ Probably, these mothers may have had very high antibody titers to the TT, which may induce severe local reactions to the subsequent $\mathrm{Td}$ vaccination. Local pain was the most common adverse event (33.5\%) but decreased on the next day, and no difference was observed among those who had received the tetanus-based vaccine more than three times (33.2\%). Redness after $\mathrm{Td}$ vaccination appeared within 30 min after injection (5.4\%), and it was mostly mild and higher (16.7\%) in mothers who had received the tetanus vaccine more than three times. Meanwhile, there was no difference in the proportion of swelling between the two abovementioned groups. Attention to severe local reactions for pain and redness found higher in subjects received more than 3 times tetanus-containing vaccine; pain $16.7 \%$ versus $(2.7-8.6 \%)$; redness $5.5 \%$ versus $0.5 \%$. This finding is consistent with the literature that severe local reactions may occur in hyperimmunized persons..$^{13}$ In a similar study conducted in the United States, injection site reactions were the most frequent specific adverse events found in $6(4.5 \%)$ nonpregnant subjects. ${ }^{22}$ The WHO has reported that redness and swelling after Td vaccination can occur in $43 \%$ of subjects. ${ }^{13}$ Compared with this literature and previous studies on this vaccine in adolescents and children, the present study has demonstrated tolerable local and systemic reactions. . $13,18,19^{2}$

In the retrospective study, none of the swelling reactions after $\mathrm{Td}$ vaccination were confirmed as Arthus reactions, and all reactions recovered well. The proportion of premature births was $1.24 \%(n=8)$, which was less than that reported by the WHO in 2014 (12.0\%). ${ }^{23} \mathrm{~A}$ similar result was found for low birth weight (2.63\%), which was less than the incidence reported in Indonesia (10.2\%) by Basic Health Research 2013.24 This result is quite similar to the result of another study conducted in New Zealand on the administration of the Tdap vaccine $(n=9 / 793)$ and a review report of the Vaccine Adverse Event Reporting System of pregnant women $\left(n=2 / 132\right.$ reported cases). ${ }^{20}$ Another study conducted in the United States to determine whether Tdap vaccination administered during pregnancy in close intervals from prior tetanus vaccination is associated with acute adverse events in mothers and adverse birth outcomes in neonates had also reported the incidence of preterm delivery (6.6\%) and low birth weight (4.7\%). ${ }^{25}$ Compared with the abovementioned literature, the proportions of preterm delivery and low birth weight infants were lower in this study. Therefore, both the prospective and retrospective data indicate that the $\mathrm{Td}$ vaccine can be used in pregnant women and also support the recommendation of the ITAGI and the Ministry of Health.

The limitation of this study was that the diary cards were self-filled by the subjects, which can lead to different interpretations even though they have been trained. However, this difference in interpretation has been mitigated by the confirmation of health workers during the postimmunization visit. In conclusion, the Td vaccine used in the immunization program of pregnant women in Indonesia was safe and well-tolerated.

\section{Conflict of Interest}

Hindra Irawan Satari, Julitasari Sundoro, Andrijono, Syafriyal, and Sri Rezeki Hadinegoro received grant support through their institutions. Mita Puspita, Rini Mulia Sari, and Novilia Sjafri Bachtiar were employees of PT Bio Farma at the time of the conduct of this study and manuscript preparation.

\section{Acknowledgment}

We acknowledge the following colleagues for their contributions to the study and the staff of the Primary Health Center Jakarta Province for subject enrollment and data collection: Arum Handayani, Santi, Poppy, Ade for their help in data collection from the field, and the Director of Research and Development of Bio Farma, Sugeng Raharso for his support in this research.

\section{Funding Sources}

This study was supported by PT Bio Farma, Indonesia.

\section{REFERENCES}

1. World Health Organization. Safety of immunization during pregnancy. A review of the evidence. Global Advisory Committee on Vaccine Safety [Internet]. Geneva: World Health Organization; 2014 [cited 2018 Oct 8]. Available from: https:// www.who.int.

2. Indonesian Ministry of Health. Indonesia health profile 2015 [Internet]. Jakarta: Indonesian Ministry of Health; 2015 [cited 2017 Apr 9]. Available from: http://www.depkes.go.id/ resources/download/pusdatin/profil-kesehatan-indonesia/ Profil-Kesehatan-Indonesia-2015.pdf. Indonesian.

3. Sur DK, Wallis DH, O'Connell TX. Vaccinations in pregnancy. Am Fam Physician. 2003;68(2):299-304.

4. Centers of Disease Control and Prevention (CDC). Updated recommendations for use of tetanus toxoid, reduced diphtheria toxoid, and acellular pertussis vaccine (Tdap) in pregnant women-Advisory Committee on Immunization Practices (ACIP), 2012. MMWR Morb Mortal Wkly Rep. 2013;62(7):131-5. 
5. Galazka A. The changing epidemiology of diphtheria in the vaccine era. J Infect Dis. 2000;181 (Suppl 1):S2-9.

6. Muchlastriningsih E. Vaccine preventable disease in Indonesia. Cermin Dunia Kedokteran. 2005;148:5-11. Indonesian.

7. Kajian vaksin $\mathrm{Td}$ untuk penanggulangan kejadian luar biasa difteri di daerah risiko tinggi. Komite Penasehat Ahli Imunisas Nasional. SK. Menkes No. 904/MENKES/SK/VII/2010 (Mei.31, 2010).

8. Kementerian Kesehatan RI Direktorat Jenderal Pencegahan dan Pengendalian Penyakit (Jakarta, Indonesia). Letter to: Kepala Dinas Kesehatan Provinsi Seluruh Indonesia (Indonesia). 2016 Apr 11. 1 leaf. Pemberitahuan peralihan penggunaan vaksin TT ke Td pada wanita usia subur. No.:HK.03.03/D.1/II.2/2511/2016.

9. Fulton TR, Narayanan D, Bonhoeffer J, Ortiz JR, Lambach P, Omer SB. A systematic review of adverse events following immunization during pregnancy and the newborn period. Vaccine. 2015;33(47):6453-65.

10. Marcy SM, Kohl KS, Dagan R, Nalin D, Blum M, Jones MC, et al. Fever as an adverse event following immunization: case definition and guidelines of data collection, analysis, and presentation. Vaccine. 2004;22(5-6):551-6.

11. Gidudu J, Kohl KS, Halperin S, Hammer SJ, Heath PT, Hennig R, et al. A local reaction at or near injection site: case definition and guidelines for collection, analysis, and presentation of immunization safety data. Vaccine. 2008;26(52):6800-13.

12. US Food and Drug Administration. Guidance for industry: Toxicity grading scale for healthy adult and adolescent volunteers enrolled in preventive vaccine clinical trials. 2007.

13. World Health Organization. Information sheet observed rate of vaccine reactions diphtheria, pertussis, tetanus vaccines. Global Vaccine Safety [Internet]. Geneva: World Health Organization 2014 [cited 2018 Oct 15]. Available from: https://www.who. int/vaccine_safety/initiative/tools/DTP_vaccine_rates_ information sheet.pdf.

14. Centers for Disease Control and Prevention. Epidemiology and prevention of vaccine-preventable disease. 13th ed. Washington D.C: Public Health Foundation; 2015.

15. Quinn JA, Munoz FM, Gonik B, Frau L, Cutland C, Mallett-Moore $\mathrm{T}$, et al. Preterm birth: case definition \& guidelines for data collection, analysis, and presentation of immunisation safety data. Vaccine. 2016;34(49):6047-56
16. Cutland $\mathrm{CL}$, Lackritz EM, Mallett-Moore $\mathrm{T}$, Bardaí $\mathrm{A}$, Chandrasekaran R, Lahariya C, et al. Low birth weight: case definition \& guidelines for data collection analysis, and presentation of maternal immunization safety data. Vaccine. 2017;35(48 Pt A):6492-500.

17. Sawyer M. Pertussis vaccine. Summary Report. Department of Health and Human Services. Centers for Disease Control and Prevention. Advisory Committee on Immunization Practices (ACIP) [Internet]. 2012 [cited 2018 Oct 8]. p. 170. Available from: https://www.cdc.gov.

18. Fadlyana E, Rusmil K, Garna H, Sumarman I, Adi SS, Bachtiar NS. Immunogenicity and Safety Td Vaccine in adolescent to prevent re-emerging disease in Indonesia. Sari Pediatri. 2013;15(3):141-9. Indonesian.

19. Sundoro J, Bachtiar NS, Syafriyal, Sari RM. Protectivity, local reactions, and systemic reaction following $t d$ vaccination among elementary school students in Indonesia. MKB. 2014;46(3):15561. Indonesian.

20. Petousis-Harris H, Walls T, Watson D, Paynter J, Graham P, Turner N. Safety of Tdap vaccine in pregnant women: an observational study. BMJ Open. 2016;6:e010911.

21. World Health Organization. Immunization, vaccine and biologicals. Tetanus [Internet]. 2018 [cited 2018 Oct 15]. Available from: https://www.who.int/immunization/diseases/ tetanus/en/.

22. Zheteyeva YA, Moro PL, Tepper NK, Rasmussen SA, Barash FE, Revzina NV, et al. Adverse event reports after tetanus toxoid, reduced diphtheria toxoid, and acellular pertussis vaccines in pregnant women. Am J Obstet Gynecol. 2012;207(1):59.e1-7.

23. World Health Organization. Preterm birth [Internet]. 2018 [cited 2018 Oct 15]. Available from: https://www.who.int/news-room/ fact-sheets/detail/preterm-birth.

24. Indonesian Ministry of Health. Indonesia health profile 2014 [Internet]. Jakarta: Indonesian Ministry of Health; 2015 [cited 2018 Oct 8]. Available from: http://www.depkes.go.id/ resources/download/pusdatin/profil-kesehatan-indonesia/ profil-kesehatan-indonesia-2014.pdf.

25. Sukumaran L, McCarthy NL, Kharbanda EO, McNeil MM, Naleway AL, Klein NP, et al. Association of Tdap vaccination with acute events and adverse birth outcomes among women with prior tetanus-containing immunizations. JAMA. 2015;314(15):1581-7. 